\title{
Importance of Contaminated Soils in Supplying Bioaccessible Fluoride to Grazing Animals From the Historic Metalliferous Mining Areas of the UK
}

\author{
Othoo Calvince Ouko 1, *, Abrahams William Peter² \\ ${ }^{1}$ School of Cooperatives and Community Development, Cooperative University of Kenya, Nairobi, Kenya \\ ${ }^{2}$ Institute of Geography and Earth Sciences, Aberystwyth University, Wales, UK
}

Email address:

oukokothoo@gmail.com (O. C. Ouko),pwa@aber.ac.uk (A. W. Peter)

${ }^{*}$ Corresponding author

\section{To cite this article:}

Othoo Calvince Ouko, Abrahams William Peter. Importance of Contaminated Soils in Supplying Bioaccessible Fluoride to Grazing Animals From the Historic Metalliferous Mining Areas of the UK. Journal of Health and Environmental Research. Vol. 2, No. 5, 2016 , pp. $27-33$. doi: $10.11648 /$ j.jher.20160205.11

Received: October 24, 2016; Accepted: November 28, 2016; Published: December 30, 2016

\begin{abstract}
Soil-plant-animal and soil-animal pathways are the principal routes through which trace element e.g fluorine (F) enters the animal body systems. It is believed that soils and herbage contaminated with such trace elements may, eventually, reflect in the bones and other animal tissues. However, the correlationship between soil $\mathrm{F}$ and Bone $\mathrm{F}$ among grazing animals has not been substantially, established. This study aimed at investigating the association between $\mathrm{F}$ concentration in soil to those found in the bones of sheep and cattle reared in metalliferous mining areas of the United Kingdom. The study area included Derbyshire, a site of fluorite $\left(\mathrm{CaF}_{2}\right)$ mineralization; Ceredigion and Mendips, sites of mostly galena $(\mathrm{PbS})$ mineralization, the latter two sites used as control sites for this study. The analytical approach involved alkali fusion, perchloric acid digestion and sequential extraction procedures in determining total soil $\mathrm{F}$, total bone $\mathrm{F}$ and soil bioavailable $\mathrm{F}$, respectively. The spectrophotometric technique was then used to determine soil $\mathrm{F}$ from solution extracts. The results showed mean total soil F concentrations of $302.3 \mathrm{mg} / \mathrm{kg}, 175.4 \mathrm{mg} / \mathrm{kg}$ and $70.8 \mathrm{mg} / \mathrm{kg}$ in Derbyshire, Mendips and Ceredigion respectively. The same order was observed for bone F with as high as $218.3 \mathrm{mg} / \mathrm{kg}, 118.1 \mathrm{mg} / \mathrm{kg}$ and $88.9 \mathrm{mg} / \mathrm{kg}$ found in Derbsyhire, Mendips and Ceredigion respectively. Analysis of Spearman rank coefficients established that there is a moderate association between soil bioavailable $\mathrm{F}$ and bone $\mathrm{F}\left(\mathrm{r}_{\mathrm{s}}=0.571\right)$, significant at $\mathrm{p}<0.1$; a conclusion suggesting possible high risk from $\mathrm{F}$ on animals grazing within heavily contaminated areas affected by historical $\mathrm{F}$ mining.
\end{abstract}

Keywords: Metalliferous, Contamination, Bioavailable, Ingestion, Association

\section{Introduction}

Involuntary ingestion of soil by grazing animals is a potential pathway to trace metal accumulation in animal tissues $[1,2]$. The major sources of these trace elements are anthropogenic including mining and smelting activities [3]. Recent studies in the United Kingdom (UK) like that of [4] revealed that grazing animals could access trace element contaminants through direct soil ingestion. There are three distinct ways the above access could be achieved, namely; animals could involuntarily ingest soil carried or stack on the herbage they feed, and uprooting herbage together with soil on the roots and this may be increased during wet conditions when the roots are loosely held. Thirdly, other animals still, may eat soil directly during periods of deficiencies to supplement trace elements in their diets [5, 6]. Again, when animals consume herbage potentially rich in trace elements, the elements may subsequently be absorbed across the stomach walls and small intestines from where it rapidly, through the blood stream, enters the mineralized tissue. The effects may vary depending on the polluter characteristics of the element absorbed and the solubility in body systems. It is also worth noting that the effect of pollution arising from trace metals is increased by factors such as; mobility and solubility of the pollutant and the ability of the pollutant to enter the food chain [7]. 
A study on trace element accumulation in sheep by [8] showed that, direct ingestion of soil by grazing animals can account for $44 \%$ or more of dry matter (DM) intake. The same study further revealed that the total daily intake of metals by sheep can be as high as $1685 \mathrm{mg}, 486 \mathrm{mg}$ and 60 $\mathrm{mg}$ for lead $(\mathrm{Pb})$, zinc $(\mathrm{Zn})$ and copper $(\mathrm{Cu})$, respectively. Another earlier study by [9] showed that grazing young sheep ingest soil $\mathrm{F}$ at moderate to high rates; in fact, an order of 69-184 mg F/day, for 63 days, was observed. These findings confirm the potential of soils in supplying $F$ to animals. Interestingly, small amounts of fluoride is believed to be essential for animal's bone development, however excess intake of fluoride by animals can potentially lead to fluorine toxicity and various organ problems as is confirmed from many sources including [10].

This study undertook to investigate the proportion of bioavailable (readily available) soil F that is actually bioaccessible (absorbed and retained in the body) by livestock. The aim was to assess how soil fluoride concentrations are reflected in the bone fluoride concentrations of animals. The specific objectives included namely; a) determining the total fluoride concentrations of the soil, b) subjecting the soils to sequential extraction procedure to assess the bioaccessible concentration of fluorine that is potentially available for absorption by animals, and finaly, c) analysis of bones F contents and relate the found concentrations with the corresponding soil samples. The analysis of fluoride was achieved through a sequential extraction procedures (SEPs) methodology that involved an addition of specific reagents to a soil in order to extract trace elements held in a particular soil phases thus validating bioaccessibility and bioavailability of fluoride.

\section{Methodology}

\subsection{Study Area}

The study was done in three regions; Derbyshire, an area of fluorspar mineralization; Ceredigion, an area important especially for the exploitations of the lead ores and the Mendips which also an area of historical lead mining. The latter two areas are used as control sites; high fluorine content was not expected from those areas, as assumed at the beginning of the study. Sample of soils and animal bone were collected from the mineralized and mined areas of the peak district (Derbyshire), Ceredigion and on the Mendips by the University of Bristol, UK and the samples were passed to Aberystwyth University for subsequent preparation and analysis.

\subsection{Sample Collections}

Soil sampling: Top soil $(0-15 \mathrm{~cm}$ depth) samples were collected from a ' $\mathrm{W}$ ' shaped traverse that was walked across selected fields composed of beef, dairy and sheep farms. Representative topsoil samples were collected by bulking at least 25 subsoil cores using a hand screw auger. Majority of samples obtained were from Derbyshire while two samples each came from the control areas (Mendips and Ceredigion).

Bone sampling: Ten metacarpus sheep and cattle bone samples were selected for this study. Bristol University as a licensed abattoir operator in the United Kingdom was well placed to provide the bone samples. The fresh and fleshy bones were kept frozen in the freezer before they were ready for preparation and analysis.

\subsection{Soil Sample Preparation}

Soils were air-dried $\left(\sim 30^{\circ} \mathrm{C}\right)$ as recommended in the Community Bureau of Reference (BCR) sequential extraction procedures $[11,12]$ before being stored at $4^{\circ} \mathrm{C}$ in a desiccator to prevent any further microbial action on the form of the trace elements [12]. Prior to analysis, soils were disaggregated using a clean porcelain pestle and mortar and sieved through a $<2000 \mu \mathrm{m}$ nylon mesh sieve and stored in labelled polyethylene bags. For each soil, a sub-sample was taken and further disaggregated before being passed through a $<180 \mu \mathrm{m}$ nylon mesh sieve and stored in labelled polyethylene bags. The $<180 \mu \mathrm{m}$ samples were retained for analysis.

\subsection{Bone Sample Preparation}

The bones were then oven dried at $100^{\circ} \mathrm{C}$ for three days to loosen the flesh and dispel their smell. The bones were then sawed into halves to expose and facilitate removal of marrow fat. The bones were then dried at $105^{\circ} \mathrm{C}$ for 18 hours in an oven. A hammer was used to break and reduce the bones into reasonable small fractions. An automated mortar was used to further grind the small bone pieces to a finer grade capable of passing through the $2 \mathrm{~mm}$ sieve. Bigger samples were rehammered to achieve a good small sizes fitting for the mortar. The $<2 \mathrm{~mm}$ samples were further ground to pass through the $<180$ microns sieve- this fractions is assumed to be the best for analysis as it offers higher surface area for reactivity (surface area to volume ratio). The refined samples of the bones were oven dried at $30^{\circ} \mathrm{C}$ for three days.

\subsection{Total F Determination in Soils}

The method used for this study was an alkali fusion method developed by [5] The soils samples were oven-dried for 16 hours at $105^{\circ} \mathrm{C}$ prior to the digestions. A certified reference material was also included in the analysis for quality control (accuracy) assessment and it was treated in a similar way as the soil samples.

\subsection{Determination of Total F in Bones}

The procedure was similar to that used for determination of total soil $\mathrm{F}$ described in section $\mathrm{E}$ above, except an addition of $1.2 \mathrm{~g}$ of $\mathrm{Na}_{2} \mathrm{CO}_{3}, 0.5 \mathrm{~g}$ of silica added to the bone samples just before fusion. This addition of silica enhances the formation of the fusion cake in the crucibles and it prevents stickiness of the cake on the walls of the crucibles thus making the process of emptying its content easier. In all the cases, $0.2 \pm 0.005 \mathrm{~g}$ of the $<180 \mu \mathrm{m}$ bone samples were used. The samples solutions were kept at $4^{0} \mathrm{C}$ awaiting $\mathrm{F}$ 
determination via spectrophotometric techniques.

\subsection{Determination of Bioavailable Soil F}

Unique Sequential Extraction Procedures (SEP) methods were used for the extraction of $\mathrm{F}$ in bones as developed by Hedley in 1994 [4, 5, 12], there are four phases of SEPs for $F$ extraction:

a) $\mathrm{NaCl}$ soluble $\mathrm{F}$ - determines the plant available $\mathrm{F}$

b) $\mathrm{NaOH}$ soluble $\mathrm{F}$ - determines the $\mathrm{Fe} / \mathrm{Al}$ oxide bound $\mathrm{F}$

c) $\mathrm{H}_{2} \mathrm{SO}_{4}$ soluble $\mathrm{F}$ - determines the $\mathrm{Ca}$ and phosphate bound $\mathrm{F}$

d) $\mathrm{Na}_{2} \mathrm{CO}_{3}$ soluble fluoride - determines the residual mineral phase $\mathrm{F}$

Only the first two phases of extraction was done in order to quantify the readily available soil $\mathrm{F}$ to plants and animals, assuming the other faces as minimal.

\subsection{Determination of F from Sample Solutions}

Spectrophotometric (Ultra Violet Visible Spectrophotometry, UV-Vis) method was used to determine the $\mathrm{F}$ contents of the various samples solutions.

\subsection{Analytical Quality Control}

As part of analytical quality control (AQC), good laboratory practices were followed to ensure the quality, integrity and reliability of the data. Milli Q deionised water was utilized throughout the analysis and the laboratory kept clean and disinfected. All reagents used were of Analar grade. Precision of the total digestion and SEP were analyzed by doing randomly chosen samples in triplicate respectively. About $10 \%$ of total samples included procedural blanks in order to identify background contamination. All samples, repeats, blanks and CRMs were analyzed randomly to minimize human bias.

The accuracy of the soil analyses was determined by calculating the recovery (\%) of $\mathrm{F}$ from the Certified Reference Material (CRM GBW 07401; certified value $=506 \pm 19 \mathrm{mg} / \mathrm{kg} \mathrm{F}$ ). The CRM was subjected to the same procedure of total digestion and SEPs as other samples.

The percent recovery was calculated using the following equation:

\section{Recovery $(\%)=$ mean concentration for CRM/Certified} concentration for CRM x 100

About $>54.7 \%$ recovery was achieved by total digestion, a figure that demonstrates the challenging procedure of $\mathrm{F}$ extraction. It can also be observed, that the available F (SEP1 $+\mathrm{SEP} 2$ ) in the CRM was approximately $12 \%$ (compare to total soil $\mathrm{F} \mathrm{CV}=54.7 \%)$ of the certified value $(506 \pm 19)$.

Table 1. Ccuracy expressed as parent recovery of the Certified Reference Material.

\begin{tabular}{llll}
\hline & Total soil F & SEP1 & SEP2 \\
\hline Certified value $(\mathrm{mg} / \mathrm{Kg})$ & $506 \pm 19$ & $506 \pm 19$ & $506 \pm 19$ \\
Concentration $(\mathrm{mg} / \mathrm{Kg})$ & 276.8 & 8.0 & 55.2 \\
Recovery $(\%)$ & 54.7 & 1.6 & 10.9 \\
\hline
\end{tabular}

\section{Results}

The total soil $\mathrm{F}$ concentrations obtained from soil analysis indicated that Derbyshire is higher in soil F concentrations than those observed for the control areas (Table 2). The difference between bioavaialble soil $\mathrm{F}$ and the total soil $\mathrm{F}$ gives the results of SEPs 3 and SEPs 4 as proposed by [13]. The sum of the SEPs 1 and 2 provided soil bioavailable $F$ (BF). Bioavailable fluoride is the amount of $\mathrm{F}$ from the soil that is readily accessible by grazing animals. Essentially, the sums of SEPs 1, 1, 3 and 4 should approximate total soil $F$ (SF) in absolute situation, however due to complexity o fluoride analysis and considering that the outcomes of the
SEPs 3 and 4 are minimal, the researcher assumed the difference for the results of the two steps.

There is a high variability in the results for the bone $\mathrm{F}$ concentrations as shown (Table 3) by the coefficient of variation values (i.e. $19.7 \%, 19.4 \%$ and $46.3 \%$ for the three sites, respectively). The median bone $\mathrm{F}$ concentrations (measured on dry weight basis) show Derbyshire highest $(210.7 \mathrm{mg} / \mathrm{kg}$ ) then Mendips and Ceredigion $(130.3 \mathrm{mg} / \mathrm{kg}$ and $85.4 \mathrm{mg} / \mathrm{kg}$, respectively). Bone are important site for $\mathrm{F}$ storage in animal tissues; investigating the concentrations of bone $\mathrm{F}$ can therefore give evidence of potential exposure to toxic levels of F. Table 3, on the other hand, show results of total bone $\mathrm{F}$ concentrations from Derbyshire and control areas.

Table 2. Total soil F and bioavailabe soil F concentrations from Derbyshire and the control sites.

\begin{tabular}{llll}
\hline Sample site & Total soil F (SF) $(\mathbf{m g} / \mathbf{k g})$ & Bioavailable soil F $(\mathbf{B F}=\mathbf{E P 1 + S E P 2}) \mathbf{( m g / \mathbf { k g } )}$ & Bioavailable soil F as a \% of total Soil F (BF/S F*100) \\
\hline Derbyshire & 241.3 & 74.2 & 30.74 \\
& 270.6 & 55 & 20.33 \\
591.7 & 44.9 & 7.58 \\
201.9 & 33.9 & 16.79 \\
207.1 & 26.9 & 13.00 \\
246.6 & 52.8 & 21.40 \\
& 313.2 & 3.4 & 3.08 \\
191.6 & 70 & 36.51 \\
& 506.5 & 54.8 & 10.81 \\
\hline
\end{tabular}




\begin{tabular}{llll}
\hline Sample site & Total soil F $(\mathbf{S F})(\mathbf{m g} / \mathbf{k g})$ & Bioavailable soil F $\mathbf{( B F = E P 1 + S E P 2 )}(\mathbf{m g} / \mathbf{k g})$ & Bioavailable soil F as a \% of total Soil F $(\mathbf{B F} / \mathbf{S ~ F * 1 0 0 )}$ \\
\hline \multirow{3}{*}{ Mendips } & 352.8 & 56.7 & 16.06 \\
& 191.3 & 60.8 & 31.76 \\
\multirow{2}{*}{ Ceredigion } & 159.6 & 34.7 & 21.74 \\
& 96.6 & 42 & 43.50 \\
& 45.1 & 35.3 & 78.27 \\
\hline
\end{tabular}

Table 3. Results of total $F$ in the bone samples from the three sample areas.

\begin{tabular}{lll}
\hline Sample site & Types of animals samples & Bone F concentrations $\mathbf{~ ( m g / k g )}$ \\
\hline Derbyshire & Sheep & 246.4 \\
& Sheep & 197.7 \\
& Sheep & 210.7 \\
Mean & 218.3 \\
CV (\%) & 19.7 \\
Mendips & Lambs & 131.4 \\
& Lambs & 92.6 \\
& Lambs & 130.3 \\
& Mean & 118.1 \\
CV (\%) & 19.4 \\
Ceredigion & Cattle & 57.4 \\
& Cattle & 72.9 \\
& Cattle & 98 \\
& Cattle & 127.3 \\
& Mean & 88.9 \\
& CV (\%) & 46.3 \\
\hline
\end{tabular}

\section{Discussion}

\subsection{Total Soil F Concentration Within the Study Areas}

The mean concentrations from the areas were $302.3 \mathrm{mg} / \mathrm{kg}$ for Derbyshire, $175.4 \mathrm{mg} / \mathrm{kg}$ and $70.8 \mathrm{mg} / \mathrm{kg}$ for Mendips and Ceredigion, respectively. The present study however, recorded lower soil $\mathrm{F}$ (mean $\sim 302 \mathrm{mg} / \mathrm{kg}$ ) than the values recorded from a similar study conducted on some selected farms in 2010 (mean $16000 \mathrm{mg} / \mathrm{kg}$ ) [14]. Again, compared to the work of [14] where values in the range of $200-80,000$ $\mathrm{mg} / \mathrm{kg}$ were recorded, the soil $\mathrm{F}$ results determined from the current study, were, comparatively, low. These findings show that the mean concentrations of $\mathrm{F}$ including majority of Derbyshire soils are within the average mean range of total soil F for most of the UK soils, which is between 200-400 $\mathrm{mg} / \mathrm{kg}$ (Fuge \& Andrews cited in [15]. However, obviously some samples from Derbyshire are above this UK soils' $F$ mean as can be observed in Figure 1. Higher soil enrichments of $F$ are observed in Derbyshire compared to the concentrations within the control areas. This is expected considering that Derbyshire is an area of historic fluorite mining and fluorite mineralization.

Normally, the concentration of contaminants is higher nearest to the mine area and decreases gradually with distance away [16]. Several factors could be attributed to the low levels of soil F recovery. First; the low total soil F from the control areas might be attributed to the normal $\mathrm{F}$ background levels which are characteristic of many soils. The areas neither have fluorite mineralization nor experienced fluorite related mining activities [17].

Derbyshire on the other hand, sustained historic fluorite mining, and thus such findings would be expected. It is also important to note that basing on our recovery accuracy, these soil's total soil $\mathrm{F}$ concentrations might be an underestimation (recovery $54.7 \%$, Table 1), and in actual fact the soils might have double the concentrations recorded in this study. For example looking at the recovery result of a sample i.e $506.5 \mathrm{mg} / \mathrm{kg}$ in Derbyshire which was at $54.7 \%$, a recovery of $100 \%$ would give $\sim 926 \mathrm{mg} \mathrm{F} / \mathrm{kg}$ which is relatively higher than the trigger concentrations.

Additionally, the results of the soil $\mathrm{F}$ were investigate relative to the concentration standards given by the Interdepartmental Committee on the Redevelopment of Contaminated Land (ICRCL, Guidance Note 70/90) of 1990 [18]. The ICRCL gives the threshold trigger and threshold maximum concentrations of fluoride contaminants upon which we compare the conformity of the analysed concentrations (Figure 1). The maximum concentration threshold is the limits beyond which zootoxic effects may lead to death.

Table 4. Calculated mean $p H$, total soil $F$ and bioavailable soil $F$ for the three study sites.

\begin{tabular}{lllll}
\hline Mean concentrations & $\mathbf{p H}$ & Total soil F $(\mathbf{S F}) \mathbf{( m g / \mathbf { k g } )}$ & $\begin{array}{l}\text { Bioavailable soil F (BF=EP1+SEP2) } \\
(\mathbf{m g} / \mathbf{k g})\end{array}$ & $\begin{array}{l}\text { Bioavailable soil F as a \% of total Soil F } \\
(\mathbf{B F} / \mathbf{S ~ F} \mathbf{1 0 0})\end{array}$ \\
\hline Derbyshire & 5.97 & 302.3 & 57 & 22.81 \\
Mendips & 6.28 & 175.4 & 47.7 & 26.75 \\
Ceredigion & 5.31 & 70.8 & 38.6 & 60.89 \\
\hline
\end{tabular}




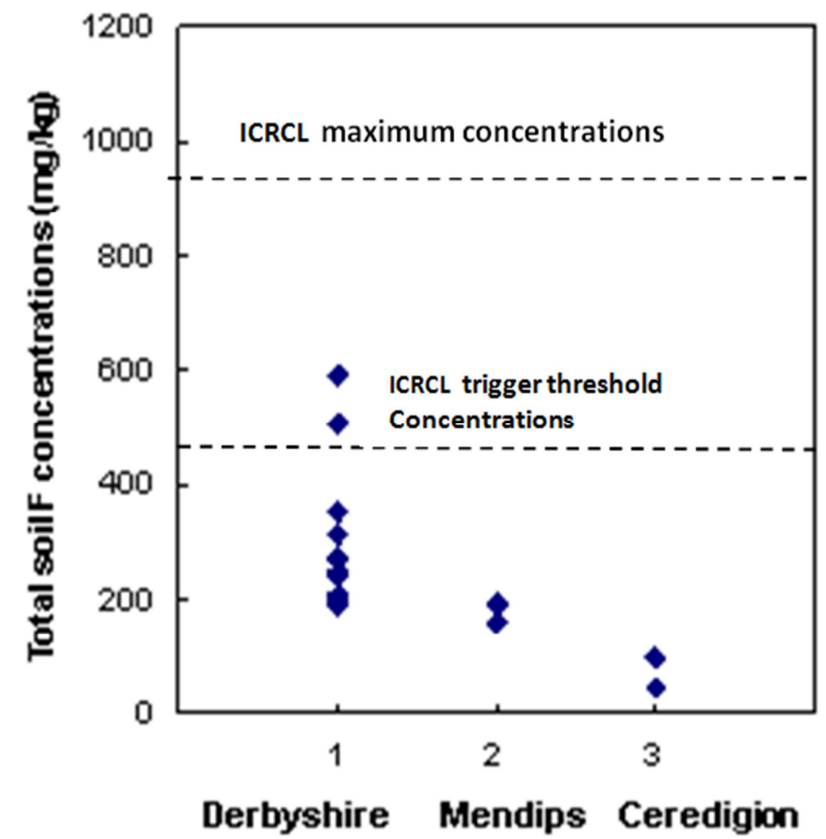

Figure 1. Threshold limits for F concentrations in soils according to the ICRCL threshold limits for fluoride.

On the other hand, the trigger threshold limits are the concentrations bellow, which there land area is considered safe. In between these two limits, exposure may lead to subclinical effects on the exposed animals. Excessive $\mathrm{F}$ intake by animals has been associated with certain bone and teeth deformities, osteoporosis among others. Once ingested, $\mathrm{F}$ readily reacts with calcium in the blood to form $\mathrm{CaF}_{2}$, which is then incorporated into the bone crystal lattice causing elevated concentrations in the bone that may then lead to bone exostoses ${ }^{1}$.

In terms of total soil $\mathrm{F}$, two soil samples from Derbyshire have concentrations above the trigger concentrations $(500 \mathrm{mg}$ $\mathrm{F} / \mathrm{kg}$ soil), suggesting potential subclinical effects on animals exposed following grazing on such contaminated soils.

\subsection{Total Bone F Concentrations}

In order for $\mathrm{F}$ to be accessible to animals, it has to be readily available for absorption following soil or herbage ingestion as discussed previously. This study paid particular interest on the importance of soil supplying bioaccesible F, the amount of $F$ that is soluble in the digestion system of an animal and is in a potentially available form for absorption. The Kruskal-Welis $H$ test revealed that the three regions were not significantly $(\mathrm{p}<0.05)$ (critical value $=5.44)$ different with regard to animal bone $\mathrm{F}$ concentrations.

Derbyshire samples further showed, a visibly, higher total bone $\mathrm{F}$ concentrations than those of the controls. The bone $\mathrm{F}$ values obtained in this study were within the normal range of most bone $\mathrm{F}$.

The normal levels of $\mathrm{F}$ in livestock are considered to be

${ }^{1}$ The formation of new bone on the surface of a bone, may cause excessive pain and deformity on bones
$200-600 \mathrm{mg} / \mathrm{kg}$ in bones (dry basis), and $200-500 \mathrm{mg} / \mathrm{kg}$ in teeth. In cattle, toxicosis is associated with levels $>5,500$ $\mathrm{mg} / \mathrm{kg}$ in compact bone.

Previous research indicates that proximity to contaminated areas is a key factor in determining exposure to $\mathrm{F}$ by animals; for example, mean $\mathrm{F}$ concentrations of $7000-8000 \mathrm{mg} / \mathrm{kg}$ were observed in the bones of small mammals near an aluminum smelter [19].

Aluminium smelting is an important source of $\mathrm{F}$ emission to the environment. However, the fact that the bone F levels were low does not rule the existence of bioaccumulation of $\mathrm{F}$ in bones as this is highly alluded to in the higher bone F from Derbyshire soils which are, of course, higher in soil F as well. The low bone F could be attributed to the length of time the affected animal species had lived on the farms, a factor important because time of exposure affects bone $\mathrm{F}$ accumulation [20,21].

\subsection{Relationship Between Bioavailable Soil F and Total Soil F}

The uptake of fluoride by animals is determined by the route of exposure, the bioavailability of the fluoride and the uptake/excretion kinetics in the organism [13]. It is now known that soil is an important source of trace elements into animals and excessive absorption may occur if the soils are contaminated from historic mining activities [16, 22]. Bioavailable $\mathrm{F}(\mathrm{BF})$ is the amount of soil $\mathrm{F}$ which is actually readily available for absorption by animals either through the soil-animal-plant pathway or the soil-animal pathway $[15,8$, 4]. Once in the body, F and other trace elements may be retained and absorbed into tissues through the process of bioaccumulation and the effects of such accumulation, beyond given thresholds, are well documented $[1,2]$. In this study, soil bioavailable F (Table 2) was calculated under the assumption that the bioavailable $\mathrm{F}$ is mostly bound within these phases of soil partitioning. This argument builds from previous studies, which tried to link results of SEPs with solubility and bioaccessibility of trace elements [24]. It is the more soluble fractions of the bound soil $\mathrm{F}$ that would readily be absorbed across the intestinal walls with the strongly bound F likely to be excreted by animals without absorption [7]. However, in vitro studies and, if possible, in vivo studies are needed to validate these assumptions.

However, a weak positive correlation $\left(\mathrm{r}_{\mathrm{s}}=0.078\right)$ exists for our case between total soil $\mathrm{F}$ and bioavailable F (Figure 2). These clearly show that the calculated bioavailable $\mathrm{F}$ from the soils used in this study did not have any association to the total concentrations of $\mathrm{F}$ in the soil $\mathrm{F}$. The results of the bioavailable soil $\mathrm{F}$ expressed as a ratio to total soil $\mathrm{F}$ was approximately $22.8 \%$ for Derbyshire and a little higher for Mendips and Ceredigion, an outcome which may mean that a considerable amount of soil F is actually available for animals' uptake. In most soils, it is the more soluble F content in soils that is biologically important to plants and animals.

Soil bioavailable F may also vary depending on the time of 
sample collection $[25,26]$; for example, during the rainy season, much of the soil $\mathrm{F}$ may be present in more readily available forms than during the dry seasons (summer months). Other factors like type of soils, rate of soil erosion and leaching may also exert influence on the amount of total soil $\mathrm{F}$ that is actually bioavailable. The $\mathrm{pH}$ and the formation of complexes of aluminum and calcium also affect the mobility and transformation of $\mathrm{F}$ in soil $[6,25]$. Adsorption to the soil solid phase is stronger at slightly acidic $\mathrm{pH}$ values $(\mathrm{pH}=5.5-6.5)$ which was the range to most of the soils used in this study.

Certain factors like type of soils, rate of soil erosion and leaching may also exert influence on the amount of total soil $\mathrm{F}$ that is actually bioavailable. Generally, the results of the study gave grater hints of the existence between soil $\mathrm{F}$ concentrations and the bioavailable soil $\mathrm{F}$ for animals.

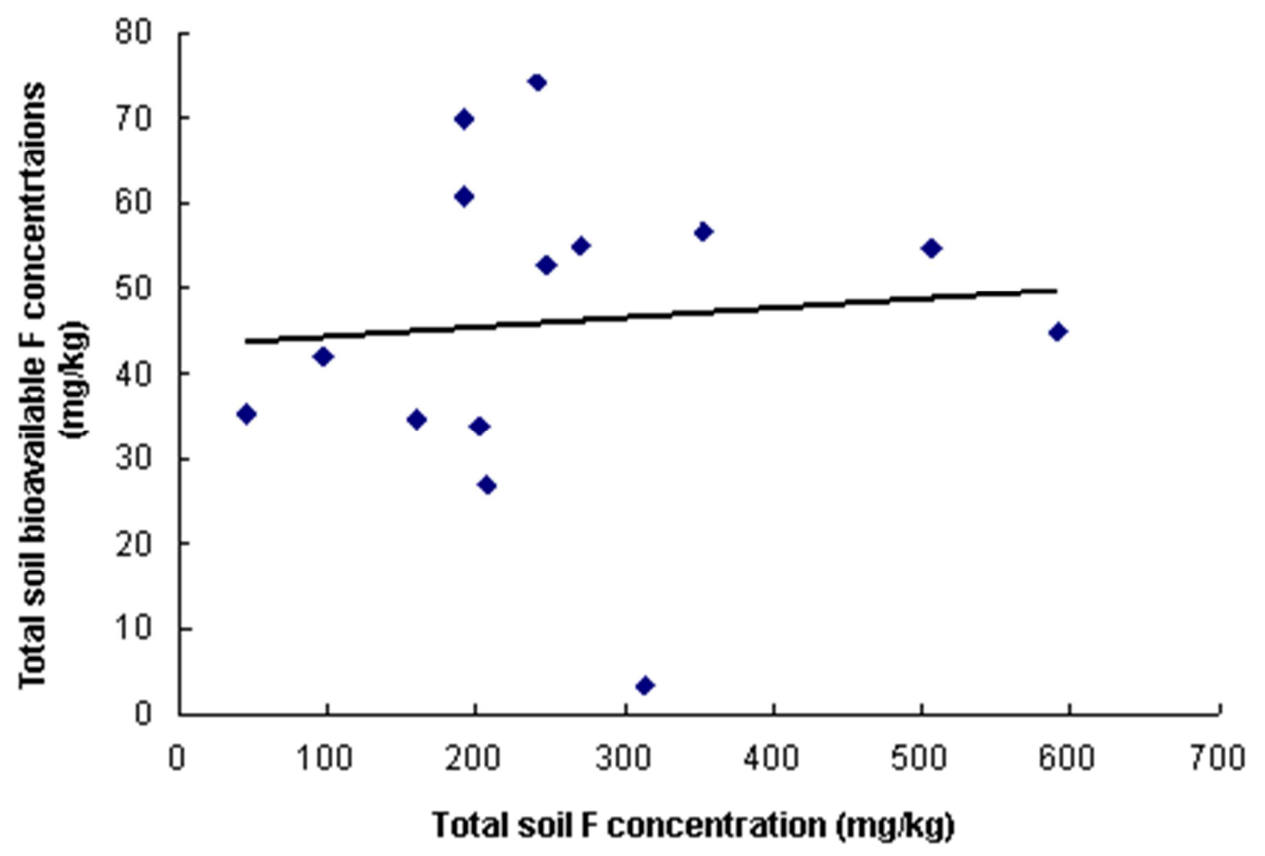

Figure 2. Relationship between total soil bioavailable F $(S E P 1+S E P 2)$ and total soil F concentration of the three study areas.

\section{Conclusions and Recommendation}

The study concluded that no significant correlation exist between total soil $\mathrm{F}$ and bone $\mathrm{F}$ was realized, although, a moderate positive association was found to exist between soil bioavailable fluoride and bone fluoride $\left(\mathrm{r}_{\mathrm{s}}=0.571\right)$, significant at $\mathrm{p}<0.1$ level of confidence. However, a moderate accuracy in the recovery $(54.7 \%)$ of the certified reference material value was obtained from total soil fluoride analysis, a value clearly indicating an underestimation in the determination of total soil fluoride and bioavailable soil fluoride. The values obtained in this research may be higher in practical situation where $100 \%$ recovery were achieved.

Nevertheless, Derbyshire soils were more enriched in soil fluoride with some samples having concentrations beyond the action trigger ICRCL thresholds; the control areas were relatively lower in soil F. Some level of evidence existed to prove that the increased soil fluoride measurements recorded in Derbyshire were reflected in the bone F concentrations of the animals from the area. This finding is significant considering that such soils enriched in fluoride exhibit higher bioavailble fluoride, which, potentially, translates to bone fluoride when ingested by animals and there is some evidence that the higher soil bioavailable soil F of Derbyshire have directly contributed to the high bone fluoride recorded.
The study, however, recommended an elaborate simulated study of ovine or bovine gastro-intestinal tract during in vitro studies as this can be a more effective way of assessing soil $\mathrm{F}$ as well as effects of short term exposure; SEPs are good but simulated digestion may reveal more information on bioaccessibility of $\mathrm{F}$ across the animal gut.

\section{References}

[1] N. D. Grace, P. Loganathan, and M. J. Hedley, "The effect of age on the fluoride concentration in the metacarpus of grazing sheep in New Zealand", in New Zealand Veterinary Journal, 56 (3), pp. 115-119, 2008.

[2] N. D. Grace, P. Loganathan, and M. J. Hedley, "The effect of a temporal change in ingestion rates of fluorine $(F)$ in soil on the concentration of $\mathrm{F}$ in serum and bone of young sheep", in New Zealand Veterinary Journal, 55 (2), pp. 77-80, 2007.

[3] K. Krishna, and P. K. Govil, "Soil contamination due to heavy metals from an industrial area of Surat, Gujarat, Western India", in Environment Monitoring Assessment, pp. 124: 263275, DOI 10.1007/s10661-006-9224-7, 2007.

[4] P. W. Abrahams, and N. B. Blackwell, "The importance of ingested soils in supplying fluorine and lead to sheep grazing contaminated pastures in the Peak District mining area of Derbyshire, UK", in Environmental Science and Pollution Research, Springer-Verlag, 11356-013-1826-3, 2013. 
[5] R. Fuge, "The automated colorimetric determination of fluorine and chlorine in geological samples", in Chemical Geology, vol.17, pp. 37-43, 1976.

[6] D. T. Waugh, W. Potter, H. Limeback, and M. Godfrey, "Risk Assessment of Fluoride Intake from Tea in the Republic of Ireland and its Implications for Public Health and Water Fluoridation", in International Journal of Environmental Research and Public Health, 13 (3), pp.259, 2016. Available online, http://doi.org/10.3390/ijerph13030259.

[7] L. Xu, K. Luo, F. Feng, and J. Tan, "Studies on the chemical mobility of fluorine in rocks", in Research report Fluoride, 39 (2)145, China, 2006.

[8] M. Smith, P. W. Abrahams, M. P. Dagleish and J. Steigmajer, "The intake of lead and associated metals by sheep grazing mining-contaminated floodplain pastures in Mid-Wales, UK: Soil ingestion, soil -metal partitioning and potential availability to pasture herbage and livestock", in Science of the Total Environment 407 (5), pp. 3731-3739, 2009.

[9] N. D. Grace, P. Loganathan, M. W. Deighton, G. Molano, and M. J. Hedley, "Ingestion of soil fluorine: its impact on the fluorine metabolism of dairy cows", in New Zealand Journal of Agricultural Research, vol. 48: pp. 23-27, 2005.

[10] C. Zhua, J. Chen, H. Zheng, Y. Wu, and J. W. Xu, "A colorimetric method for fluoride determination in aqueous samples based on the hydroxyl deprotection reaction of a cyanine dye".

[11] P. Quevauviller, A. Ure, H. Muntau, and B. Griepink, "Improvement of analytical measurements within the BCRprogramme: single and sequential extraction procedures applied to soil and sediment analysis", International Journal of Environmental Analytical Chemistry, vol. 51, pp. 129-134, 1993.

[12] M. Ure, P. Quevauviller, H. Muntau, and B. Griepink, "Speciation of heavy metals in soils and sediments: An account of the improvement and harmonization of extraction techniques undertaken under the auspices of the BCR of the Commission of the European Communities", International Journal of Environmental Analytical Chemistry, Vol. 51, pp. 135-151, 1993.

[13] P. Loganathan, C. W. Gray, M. J. Hedley and H. C. Roberts, "Total and soluble fluorine concentrations in relation to properties of soils in New Zealand", European Journal of Soil Science, vol.57, pp. 411-421, 2006.

[14] N. L. Blackwell, "The chemical partitioning of fluorine, lead and associated metals in soils of the historic metalliferous mining area of Derbyshire, UK: implications of involuntary soil ingestion to sheep", A Thesis Submitted in partial fulfilment of the Requirements of Aberystwyth University for the Degree of Master in Environmental Monitoring and Analysis. Aberystwyth University, UK, 2010.
[15] N. A. Geeson, P. W. Abrahams, M. P. Murphy, and I. Thornton, "Fluorine and metal enrichment of soils and pasture herbage in the old mining areas of Derbyshire, UK", Agriculture, Ecosystems and Environment, 68 (3), pp. 217$231,1998$.

[16] B. E. Davies, "Heavy metal contamination from base metal mining and smelting: implications for man and his environment", Applied Environmental Geochemistry. I. Thornton, London: Academic Press, 1983.

[17] D. Johnston, "A metal mines strategy for Wales", Environment Agency Wales, United Kingdom, 2004.

[18] [ICRCL] Interdepartmental Committee on the Redevelopment of Contaminated Land, "Notes on the restoration and aftercare of metalliferous mining sites for pasture and grazing", Guidance Note 70/90, Department of the Environment, 1990.

[19] [ATSDR] Agency for Toxic Substances and Disease Registry. Toxicological profile for Lead, Department of Health and Human Services, Public Health Service, Atlanta, U. S., 2007.

[20] T. A. O' Donnell, "The chemistry of Fluorine", Inorganic Chemistry, vol. 5, Pergamon Press. 1975.

[21] S. L. Choubisa, V. Modasiya, C. K. Bahura, and Z. Sheikh, "Toxicity of fluoride in cattle of the Indian thar desert, Rajasthan, India”, Research report. Fluoride vol.45 (4), pp.371-376, 2012.

[22] T. B Colman and D. C. Cooper, Exploration for Metalliferous and Related Minerals in Britain: A Guide, 2nd Ed. DTI mineral Program. Publication No. 1, 2000.

[23] Kabata-Pendias and H Pendias, Trace elements in soils and plants. London: CRC Press, 2001.

[24] G. J. Zagury, C. Bedeaux, and B. Welfringer, "Influence of mercury speciation and fractionation on bioaccessibility in soils", Archives of Environmental Contamination and Toxicology, vol.56, pp. 371-379, 2009.

[25] R. Raiswe, J. R. Hawkings, L. G. Benning, A. R. Baker, R. Death, S. Albani, N. Mahowald, M. D. Krom, S. W. Poulton, J. Wadham, and M. Tranter, "Potentially bioavailable iron delivery by iceberg-hosted sediments and atmospheric dust to the polar oceans" Biogeosciences, vol. 13, pp. 3887-3900, doi: 10.5194/bg-13-3887-2016, 2016.

[26] A. K. Tiwari, A. K. Singh and M. K. Mahato, "GIS based evaluation of fluoride contamination and assessment of fluoride exposure dose in groundwater of a district in Uttar Pradesh, India", Human And Ecological Risk Assessment, vol. $0, \quad$ No. $0, \quad 1-11, \quad$ availableonline, http://dx.doi.org/10.1080/10807039.2016.1220824, 2016. 